\title{
Farmers knowledge, perceptions and management of Kersting's groundnut (Macrotyloma geocarpum Harms) insect pests in Benin
}

\author{
Yêyinou Laura Estelle Loko ${ }^{1 *}$ (D), Jerôme Akohonwe ${ }^{1}$, Joelle Toffa ${ }^{1}$, Azize Orobiyi ${ }^{1}$, Prisca Assogba², \\ Alexandre Dansi ${ }^{2}$ and Manuele Tamò ${ }^{3}$
}

\begin{abstract}
Background: Macrotyloma geocarpum Harms is a neglected and underutilized crop in Benin subject to several constraints including storage insect attacks, which contribute to the decrease in its production. An ethnobotanical survey using a semi-structured questionnaire was conducted in 15 villages in southern and central Benin to document farmers' perceptions of $M$. geocarpum storage insect pests and their traditional management practices.

Results: The results showed that insect pest were the most important storage constraint of M. geocarpum. To overcome this constraint, the promotion of resistant landraces has been proposed by farmers. Six vernaculars names of storage insect pests of $M$. geocarpum were identified throughout the study area and all corresponding to Callosobruchus maculatus (F.) which proved to be the most abundant insect in the stocks. Palatability and fragility of seeds coat have been identified by farmers as the main factors favoring the infestation by this pest. Various storage containers of M. geocarpum have been inventoried. Our study revealed that education, storage containers, and Kersting's groundnut landraces significantly influenced farmers' perceptions of severity of insect pest damages. The use of chemicals and repellent plants were the main control methods used by farmers to protect stocks. Different levels of resistance of $M$. geocarpum landraces to storage insect pests were reported.

Conclusions: This study provides baseline information for development of integrated management approaches against storage insect pests of $M$. geocarpum. The perceived level of resistance to insect damage on Kersting's groundnut landraces needs to be investigated.
\end{abstract}

Keywords: Kersting's groundnut, Management practices, Storage constraints, Insect pests, Varietal resistance

\section{Background}

Macrotyloma geocarpum (Harms), or Kersting's groundnut, is an important African indigenous legume crop of the Fabaceae family grown on a small scale in West Africa for its grains are produced in pods developing below ground (Pasquet, Mergeai, \& Baudoin, 2002). Identified as a neglected and underutilized species in Benin (Dansi et al., 2012), Kersting's groundnut is native to and mainly grown in West Africa (Hepper, 1963). In

\footnotetext{
* Correspondence: lokoestelle@yahoo.fr

${ }^{1}$ Laboratory of Applied Entomology, Faculty of Sciences and Technology of Dassa (FAST-Dassa), National University of Sciences Technologies Engineering and Mathematics of Abomey (UNSTIM), BP 14, Dassa, Benin

Full list of author information is available at the end of the article
}

Benin, the seeds of $M$. geocarpum are particularly preferred over other grain legumes because of their high palatability (Achigan-Dako \& Vodouhè, 2006; Assogba et al., 2015). Its edible seeds are high in proteins, carbohydrates, and essential amino acids (Chickwendu, 2007). They are also a good source of minerals such as phosphorus, potassium, calcium, and sodium (Oyetayo \& Ajayi, 2005). According to Ajayi and Oyetayo (2009), Kersting's groundnut can be used in the formulation of dietary supplements for children and thus help to combat malnutrition. Moreover, it is an important source of income ( 2 to 6 USD per kilogram) for the rural population of Benin (Assogba et al., 2015). 
Unfortunately, $M$. geocarpum is on the verge to be abandoned in several countries including Benin (Assogba et al., 2015), mainly because of its poor storage capacity of seeds (Kouelo et al., 2012). In fact, a major constraint faced by farmers in post-harvest is pest attack during storage (Assogba et al., 2015; Ayenan \& Ezin, 2016). However, very little attention has been given to the constraints related to the storage of $M$. geocarpum seeds in Benin. Although Achigan-Dako and Vodouhè (2006) notified that stored seeds are very susceptible to weevils and bruchids infestations, the diversity of insect pest species associated to stored seeds of $M$. geocarpum in the production areas is still unknown, and the perception of farmers about the extent of damage caused by these pests has never been evaluated. In addition, traditional management practices used to prevent or control insect infestations have been very scarce, whereas this knowledge is needed for the development of effective integrated pest management approaches adapted to the needs of local farmers (Norton, Rajotte, \& Gapud, 1999; Van Huis \& Meerman, 1997). In this context, farmers' perceptions of storage insect pest management are key elements for the design of efficient and easily implementable control practices (Okonya, Mwanga, Syndikus, \& Kroschel, 2014).

The resistant varieties are a most economical and healthy way to minimize loss due to attack of storage insects (Badii, Asante, \& Bayorbor, 2011). However, in Benin, resistance of Kersting's groundnut landraces to storage insects and the reasons of the observed susceptibility have never been investigated. We report in this paper the findings of a study carried out in Benin in order to (1) identify Kersting's groundnut storage constraints and solutions proposed by farmers to overcome these constraints, (2) evaluate farmers' knowledge and perceptions of its storage pests, (3) examine farmers' current practices in managing its storage pests, and (4) identify landraces that have some resistance to damage by storage insect pests.

\section{Methods}

\section{Study area}

The present study was conducted in southern and central Benin which are the major production area of $M$. geocarpum (Assogba et al., 2015, Kouelo et al., 2012, Worou, Zandjanakou-Tachin, Boulga, \& BokononGanta, 2016). The south and the centre are relatively humid agro-ecological zones with bimodal rainy seasons and mean annual rainfall varying from 1.100 to 1.400 $\mathrm{mm} /$ year (Yabi \& Afouda, 2012). Mean annual temperatures range from 26 to $28^{\circ} \mathrm{C}$ (Adam \& Boko, 1993). Vegetation types are semi-deciduous forest (south), woodland and savannah (center east), and dry semideciduous forest (center west and south). The main ethnic groups are Adja, Cotafon, Holly, Ouéménou, Pédah, Saxwé, Tori, Watchi, Xwla, Yoruba, Fon, Mahi, Idaasha, Fé, and Tchabé (Adam \& Boko, 1993). Ethnobotanical survey was conducted in 15 villages selected in southern and central Benin (Fig. 1) based on the literature review, their accessibility and discussions with farmers and extension agricultural services locally named CARDER (regional action centres for rural development).

\section{Data collection}

A survey was implemented to collect data using participatory research appraisal tools and techniques, such as direct observation, individual interviews, and field visits, using a pre-established questionnaire following Orobiyi et al. (2013). The surveyed farmers in each village were selected with the assistance of the chiefs of the village but also by the "snowball" sampling method. This is a chain-sampling method that relies on the recommendations of the starting subjects to reach additional participants (Johnston \& Sabin, 2010). A total of 83 producers of M. geocarpum were surveyed throughout the study area. The data collected focused on the sociodemographic characteristics of the interviewees (sex, age, education, years of experience in the cultivation of Kersting's groundnut, area sown), the constraints related to the storage of Kersting's groundnut seeds, the periods of infestation, farmers perception of insect pests of stored Kersting's groundnut seeds, storage containers, shelf life, severity of insect pest attack, susceptibility, and resistance of Kersting's groundnut landraces to storage insects and management practices of insects in Kersting's groundnut stocks. The perception on the storage insect severity was captured as a categorical variable using a 4-point Likert scale rating (Khan et al., 2014). Farmers were asked to score for the level of damage caused by insect pests (Munyuli et al., 2017). A fourpoint scale $(0=$ no severe, $1=$ moderate severity, $2=$ severe, and 3 = very severe) was used for rating the damage level perceived. Insects identified by farmers as storage pests of $M$. geocarpum were collected and stored in labelled boxes (village, storage container, vernacular name) containing alcohol at $70^{\circ} \mathrm{C}$, for later identification in the laboratory. Similarly, plant samples used by farmers to control storage insects were collected and tagged (vernacular name of the plant, village name, and method of use) and returned to the laboratory for identification.

\section{Inventory of insect fauna associated to stored seeds of Kersting's groundnut}

In each prospected village, $300 \mathrm{~g}$ of infested Kersting's groundnut seeds was weighed using an electronic scale and collected from different storage containers from 


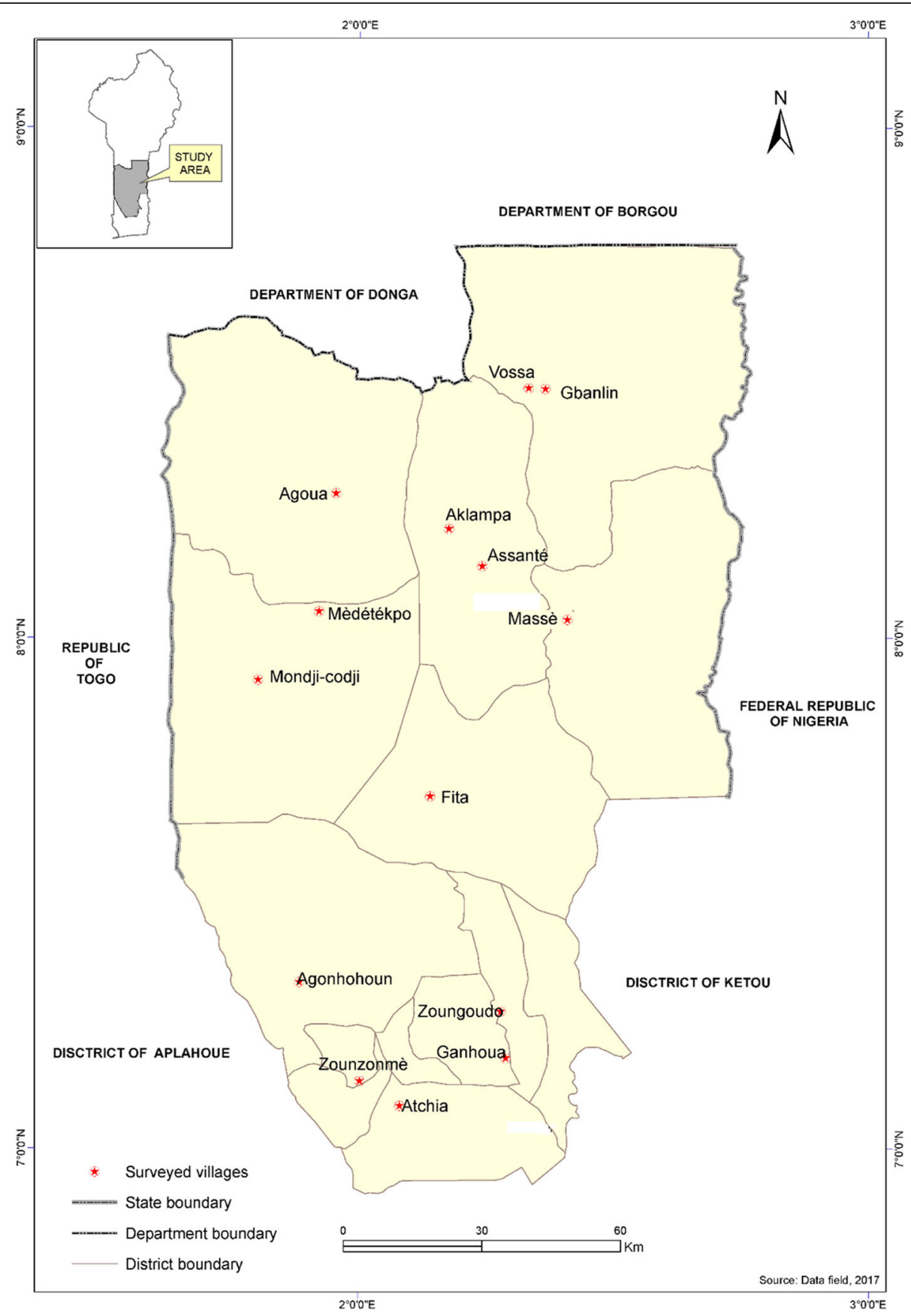

Fig. 1 Map of study area showing the geographical position of the surveyed villages

three households. The plastic boxes $(17 \mathrm{~cm}$ in height, 6 $\mathrm{cm}$ in diameter) containing the samples of infested Kersting's groundnut seeds were labelled (name of the landrace, storage form (seed or pod), storage containers and the name of the village) and incubated for 3 months under laboratory conditions $\left(25 \pm 2{ }^{\circ} \mathrm{C}, 70 \pm 5 \%\right.$ of relative humidity, and a photoperiod of 12:12 (L:D) h), following Eze, Asiegbu, Mbah, Orkwor, and Asiedu (2006) and Loko et al. (2013). After the incubation period, the samples were sieved using a sieve with a mesh of 0.25 $\mathrm{mm}$. The collected insects were counted and put in vials containing alcohol at $70^{\circ}$ for their conservation. Species' identification was done at the Laboratory of Applied Entomology of the Faculty of Sciences and Technology of Dassa-Zoumé. The determination of insect species was based on the use of Coleoptera identification keys of stored commodities Delobel and Tran (1993), Haines (1989), and Halstead (1986). 


\section{Data analysis}

The ethnobotanical data were analysed using the descriptive statistics, and the results were presented in the form of tables and graphs constructed with Excel software (Microsoft office 2016). We used an ordinal regression with a logit link (ordered logit) to explain the association between severity levels of storage insect attacks (no severe, moderate severity, severe, and very severe) and socio-demographic characteristics of surveyed farmers (age, gender, size of household, farming experience, land size, level of education), storage containers (canaries, jute bags, calabash, insecticide boxes, basin, jar, plastic buckets), and Kersting's groundnut landraces (Doyi wéwé, Doyi vovo, Doyi wiwi) using $\mathrm{R}$ software (Midega, Murage, Pittchar, \& Khan, 2016). However, for ease of interpretation of results, marginal effects were also estimated using R software (Greene, 2003; Midega et al., 2012).

\section{Results}

Socioeconomic and farm characteristics of the respondents

A total of 83 producers of $M$. geocarpum were surveyed, among them $71.1 \%$ were men and $28.9 \%$ are women. They belonged to 5 socio-cultural groups including Mahi (51.8\%), Fon (39.8\%), Idaatcha (4.8\%), Nago (2.4\%), and Tchabé (1.2\%). Their age ranged from 21 to 70 years with an average of 45 years and the age group 37-53 was instead of the most represented (Table 1). Household size ranged from 3 to 22 individuals with an average of 6 individuals. The majority of surveyed farmers $(68.7 \%)$ were illiterate, while $15.6 \%$ had primary level, $12.1 \%$ secondary level, and only $3.6 \%$ had tertiary. The surveyed farmers had an experience ranging from 2 to 48 years in the production of Kersting's groundnut with an average experience of 12 years. Kersting's groundnuts were cultivated on small plots $(0.1-1$ ha) by most farmers (54.2\%).

Table 1 Socio-demographic characteristics of surveyed households in the study area $\left(N^{*}=83\right)$

\begin{tabular}{|c|c|c|c|}
\hline Demographic characteristics & Number of farmers & Percentage (\%) & $\overline{M e a n} \pm \mathrm{SE}$ \\
\hline \multicolumn{4}{|l|}{ Level of education } \\
\hline No formal education & 57 & 68.7 & \\
\hline Primary & 13 & 15.6 & \\
\hline Secondary & 10 & 12.1 & \\
\hline University & 3 & 3.6 & \\
\hline \multicolumn{4}{|l|}{ Age (years) } \\
\hline$[21-37[$ & 23 & 27.7 & $45.5 \pm 1.3$ \\
\hline$[37-53[$ & 39 & 47 & \\
\hline [53-70] & 21 & 25.3 & \\
\hline \multicolumn{4}{|l|}{ Gender } \\
\hline Female & 24 & 28.9 & \\
\hline Male & 59 & 71.1 & \\
\hline \multicolumn{4}{|l|}{ Experience (years) } \\
\hline$[2-14[$ & 54 & 65.1 & $12.4 \pm 1.0$ \\
\hline$[14-26[$ & 19 & 22.9 & \\
\hline$[26-37[$ & 8 & 9.6 & \\
\hline [37-48] & 2 & 2.4 & \\
\hline \multicolumn{4}{|l|}{ Household size } \\
\hline$[3-9[$ & 61 & 73.5 & $6.9 \pm 0.3$ \\
\hline$[9-15[$ & 19 & 22.9 & \\
\hline [15-22] & 3 & 3.6 & \\
\hline \multicolumn{4}{|l|}{ Land size } \\
\hline$[0.1-1[$ & 45 & 54.2 & $0.8 \pm 0.0$ \\
\hline$[1-2[$ & 31 & 37.4 & \\
\hline$[2-2.5]$ & 7 & 8.4 & \\
\hline
\end{tabular}

${ }^{*} N$ number of interviewed household heads, SE standard error of the mean 


\section{Kersting's groundnut seeds storage constraints and proposed farmers solutions}

Four seeds storage constraints were identified in the study area. Among them, the most important is the attack of insects (83.6\% of responses), followed by the long duration of seeds drying (11.4\% of responses). The loss of seeds stored germination $(2.5 \%$ of responses) and the lack of good storage containers (2.5\% of responses) were of minor importance. This trend was observed throughout south and central Benin (Table 2). Only a few interviewees reported that the losses caused by storage insects were severe (15.7\% of farmers) or very severe $(13.3 \%$ of farmers), while most farmers (51.8\%) estimated that losses related to insect pest attacks are moderately severe. However, some farmers (19.2\%) believe that storage insects do not cause any losses. For most farmers (57.6\%), infestations of Kersting's groundnut by insects occur mainly between the sixth and seventh months of storage (Fig. 2). To minimize Kersting's groundnut seeds storage constraints, the farmers proposed six key solutions. Among them, the promotion of Kersting's groundnut varieties resistant to insect pests (25.6\% of responses), the use of more efficient storage containers (25.6\% of responses), and the assistance of CARDER agents in the conservation of Kersting's groundnut seeds (20.9\% of responses) were the most commonly. The promotion of more suitable chemicals insecticides ( $14 \%$ of responses), the creation of an association of Kersting's groundnut farmers (9.3\% of responses), and training farmers on techniques of production and conservation of Kersting's groundnut (4.6\% of responses) were proposed by few farmers.

\section{Farmers' knowledge of Kersting's groundnut storage insect pests}

Most farmers $(87.9 \%)$ were able to identify at least one insect species associated with stored Kersting's groundnut in their local language. In total, six vernacular names of storage insect pests were identified across sociocultural groups in the study area. They are called Sokpo$z i n$ in Fon (30.1\% of farmers), Dohi wévi in Mahi and Fon (34.3\% of farmers), Di in Fon (10.9\% of farmers), Aikoun wévi in Mahi (15.1\% of farmers), Foforo in Idaatcha (6.9\% of farmers), and Bibi dohi in Tchabé (2.7\% of farmers). All these six vernacular names literally mean "insect pests of dohi" (local name of Kersting's groundnut), and all refer to the insect pest Callosobruchus maculatus (F) (Coleoptera: Bruchidae). Although surveyed farmers identify only one species of insect pest, they use several criteria to identify Kersting's groundnut storage insect pests. The colour (black or reddish) of insects $(58.7 \%$ of responses), the pointed mouthparts $(25 \%$ of responses), the small size of insects $(6.5 \%$ of responses), the thickness of abdomen (3.3\% of responses), and the presence (3.3\% of responses), and the hardness of wings (3.3\% of responses) represent the criteria of farmers' identification of pests. According to farmers, several factors favor the attack of stored Kersting's groundnut seeds by insect pests: palatability of seeds (56.5\% of responses), fragility of their seed coat $(12.9 \%$ of responses), and high temperature inside the storage system (6.5\% of responses) were the most important factors (Fig. 3).

The diversity analysis conducted on a total of 50 insect samples taken from the stocks revealed three species of insect pests associated with Kersting's groundnut seed. These are C. maculatus (in stored Doyi wéwé, Doyi wiwi,

Table 2 Kersting's groundnut grains storage constraints and proposed solutions to overcome them throughout the study area in function of regions, gender and sociolinguistic groups

\begin{tabular}{|c|c|c|c|c|c|c|c|c|c|c|}
\hline & \multicolumn{2}{|l|}{ Regions } & \multicolumn{2}{|l|}{ Gender } & \multicolumn{5}{|c|}{ Sociolinguistic groups } & \multirow{2}{*}{$\begin{array}{l}\text { General } \\
(\%)\end{array}$} \\
\hline & South & Centre & Male & Female & Mahi & Fon & Idaatcha & Nago & Tchabé & \\
\hline Constraints & $(N=28)$ & $(N=51)$ & $(N=57)$ & $(N=22)$ & $(N=42)$ & $(N=29)$ & $(N=5)$ & $(N=2)$ & $(N=1)$ & $(N=79)$ \\
\hline Insects attacks & 78.6 & 86.3 & 84.2 & 81.8 & 85.7 & 82.7 & 60 & 100 & 100 & 83.6 \\
\hline Long duration of seeds drying & 17.8 & 7.8 & 10.5 & 13.6 & 9.5 & 13.8 & 20 & - & - & 11.4 \\
\hline Loss of seeds stored germination & - & 3.9 & 1.8 & 4.6 & 4.8 & - & 20 & - & - & 2.5 \\
\hline Lack of good storage containers & 3.6 & 2 & 3.5 & - & - & 3.5 & - & - & - & 2.5 \\
\hline Proposed solutions & $(N=14)$ & $(N=38)$ & $(N=39)$ & $(N=13)$ & $(N=30)$ & $(N=17)$ & $(N=3)$ & $(N=2)$ & $(N=0)$ & $(N=52)$ \\
\hline Farmers training & 42.9 & 34.2 & 41 & 23.1 & 33.3 & 41.2 & 33.4 & 50 & - & 36.6 \\
\hline More efficient storage containers & 7.1 & 36.8 & 25.6 & 38.4 & 40 & 11.8 & - & 50 & - & 28.8 \\
\hline Resistant varieties & 28.6 & 15.8 & 23.1 & 7.7 & 13.3 & 29.4 & 33.3 & - & - & 19.2 \\
\hline More suitable chemicals insecticides & 14.3 & 7.9 & 7.7 & 15.4 & 6.7 & 11.8 & 33.3 & - & - & 9.6 \\
\hline Creation of farmers association & 7.1 & 5.3 & 2.6 & 15.4 & 6.7 & 5.8 & - & - & - & 5.8 \\
\hline
\end{tabular}

$N$ number of interviewed household heads 


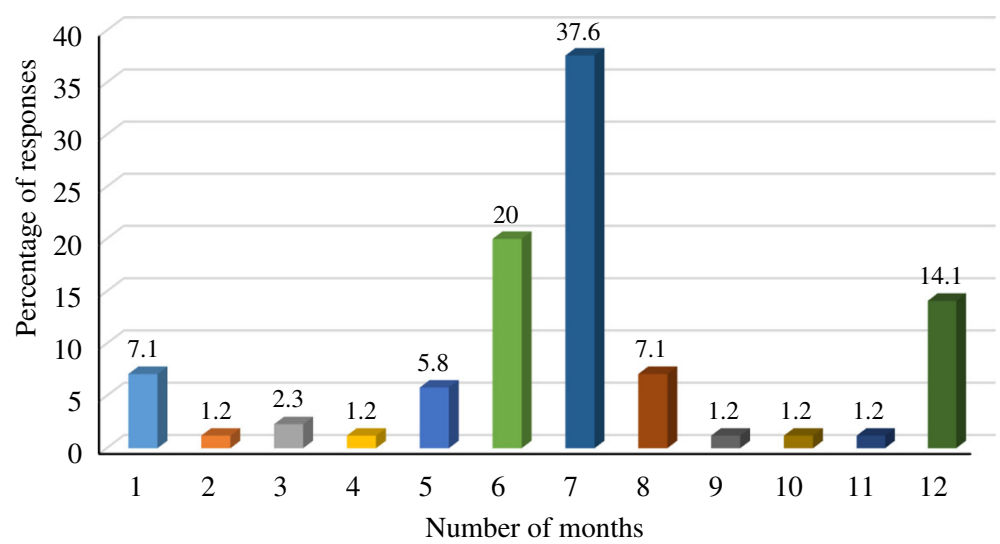

Fig. 2 Farmers' perception of the period of infestation of the Kersting's groundnut by insect pests

Doyi vovo landraces), Acanthoscelides obtectus Say (Coleoptera: Bruchidae), and Lasioderma serricorne (F) (Coleoptera: Anobiidae) (in stored Doyi wéwé landrace). Among these insects, C. maculatus was found in $82 \%$ of the samples collected and was also the most abundant (96.9\%) in all the samples in which it was found.

\section{Conservation of Kersting's groundnut seeds}

Storage containers varied from one farmer to another and depending on the amount of stored Kersting's groundnut, with plastic buckets (61.5\% of responses) and jute bags (16.9\%) being most common. Clay pots (7.2\%), insecticides boxes (6\%), basin (4.8\%), jar (2.4\%), and calabash (1.2\%) were also used as storage tools by farmers. In most of cases, only a small amount of Kersting's groundnut is stored as seed. Most of the harvested Kersting's groundnut was sold just after harvest (1 to 3 months) to avoid storage losses. Farmers estimate that Kersting's groundnut seeds can be stored for up to 6 to 8 months (79.5\% of responses) and 9 to 12 months ( $15.7 \%$ of responses) with no loss due to storage insect attack. Some farmers estimate that damage of insect can be observed in Kersting's groundnut seeds only after 1 to 2 months (2.4\% of farmers) and 3 to 5 months ( $2.4 \%$ of farmers) of storage. Highly infested Kersting's groundnut seeds are discarded by many of surveyed farmers (44.6\%). However, some farmers reported consuming (21.7\%) and making donuts and cakes for sale (22.9\%) with heavily infested seeds. Only $8.4 \%$ and $1.2 \%$ of the respondents used the infested seeds as animal feed and as planting materials.

\section{Farmers' perception of the susceptibility of Kersting's groundnut landraces to storage insect pests}

Throughout the study area, three Kersting's groundnut landraces were grown by farmers. Most farmers (72.3\%) noted differences in susceptibility of landraces to insect pests. Among them, landrace Doyi wéwé with white tegument, which is the most cultivated, is also the most susceptible to storage insect pests according to the majority of farmers (91.7\%). On the other hand, Doyi vovo

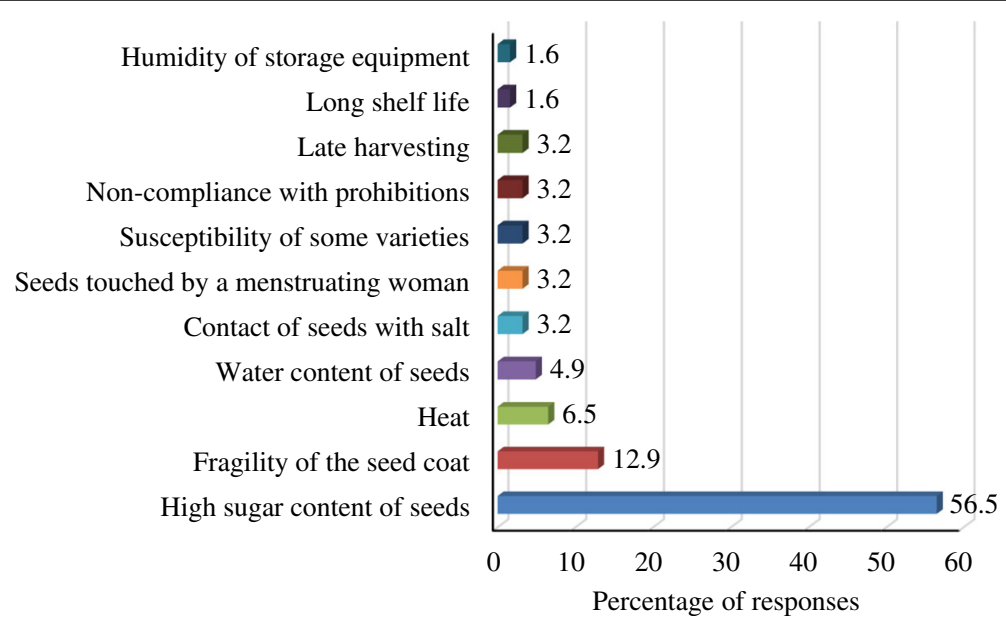

Fig. 3 Famers' perceptions of the factors favoring the attacks of stored Kersting's groundnut seeds by insects 
with red tegument and Doyi wiwi with black tegument were cited as susceptible to storage insects only by $1.7 \%$ and $6.6 \%$ of farmers, respectively. Several reasons were given to explain the susceptibility of Doyi wéwé: palatability of seeds (53.2\% of responses), high soil moisture ( $27.7 \%$ of responses), thinness of the seed coat (14.9\% of responses), late harvest ( $2.1 \%$ of responses), and high water content of seeds (2.1\% of responses). Most farmers (90.4\%) did not identify any Kersting's groundnut landraces as resistant to storage insects. Only a few farmers reported Doyi vovo (3.6\%) and Doyi wiwi (6\%) as storage insect-resistant landraces. For these farmers, the resistance of the Doyi vovo and Doyi wiwi landraces could be explained by the hardness of their seed coat but also by their non-palatable nature.

Factors influencing farmers' perceptions about severity of insect pest damages

The model of the ordered probit regression was significant at $1 \%$. The results showed that education, type of storage containers, and type of Kersting's groundnut landraces produced had a statistically significant relationship with farmers' perception of severity of storage insect damage (Table 3). Farmers who have university education level (coefficient 2.091) and those who produced Doyi vovo (coefficient 2.044) and Doyi wiwi (coefficient 1.711) landraces had positive and significant effect on farmers' knowledge of severity of storage insect attack. The marginal effects for university education and the type of cultivated landraces were significant for severe rank implying that this category of farmers was most likely to rank the attack as severe. Farmers who store Kersting's groundnut grains in jute bags perceived the pest attack as 'not severe' (coefficient -1.740). The corresponding significant marginal effects for storage in jute bags were -0.154 (for "not severe" rank), -0.121 (for "severe" rank), and - 0.086 (for "very severe" rank). The variables such as age, sex, size of household, and farming experience showed trends to having a positive effect on the level of farmers' perception of severity of

Table 3 Ordered logit results of factors influencing farmers' perception about severity of storage pest attacks on Kersting's groundnut

\begin{tabular}{|c|c|c|c|c|c|c|c|c|}
\hline \multirow[t]{3}{*}{ Variables $^{\mathrm{b}}$} & \multicolumn{2}{|c|}{ Coefficient } & \multicolumn{6}{|c|}{ Farmers perception of severity of damage by storage insect pests ${ }^{a}$} \\
\hline & \multirow[t]{2}{*}{ Coef. } & \multirow[t]{2}{*}{ Std. Err. } & \multicolumn{2}{|c|}{ Not severe } & \multicolumn{2}{|l|}{ Severe } & \multicolumn{2}{|c|}{ Very severe } \\
\hline & & & $\mathrm{dy} / \mathrm{dx}$ & Std. Err. & $\mathrm{dy} / \mathrm{dx}$ & Std. Err. & $\mathrm{dy} / \mathrm{dx}$ & Std. Err. \\
\hline Age (years) & 0.032 & 0.025 & 0.003 & 0.002 & 0.003 & 0.002 & 0.002 & 0.002 \\
\hline Gender ( 0 = female, $1=$ male $)$ & 0.562 & 0.610 & 0.048 & 0.058 & 0.050 & 0.051 & 0.038 & 0.039 \\
\hline Size of household (number) & 0.096 & 0.089 & 0.008 & 0.008 & 0.009 & 0.009 & 0.007 & 0.007 \\
\hline Farming experience (years) & 0.013 & 0.029 & 0.001 & 0.002 & 0.001 & 0.003 & 0.001 & 0.002 \\
\hline Land size (hectares) & -0.257 & 0.527 & -0.021 & 0.043 & -0.024 & 0.049 & -0.019 & 0.040 \\
\hline${ }^{\mathrm{b}}$ No education $(1=$ yes, $0=$ no $)$ & 0.175 & 0.694 & 0.014 & 0.058 & 0.016 & 0.063 & 0.013 & 0.049 \\
\hline Secondary education level $(1=$ yes, $0=$ no $)$ & 1.250 & 0.920 & 0.037 & 0.040 & 0.120 & 0.081 & 0.141 & 0.145 \\
\hline University education level $(1=$ yes, $0=$ no $)$ & 2.091 & $1.167^{*}$ & -0.039 & 0.114 & 0.146 & $0.055^{* * *}$ & 0.324 & 0.268 \\
\hline${ }^{\mathrm{C} S t o r e}$ in jute bags $(1=$ yes, $0=$ no $)$ & -1.740 & $0.995^{*}$ & -0.154 & $0.085^{*}$ & -0.121 & $0.054^{* *}$ & -0.086 & $0.039^{* *}$ \\
\hline Store in calabash $(1=$ yes, $0=$ no $)$ & 1.388 & 1.641 & 0.013 & 0.116 & 0.127 & 0.106 & 0.179 & 0.328 \\
\hline Store in insecticide boxes $(1=$ yes, $0=$ no $)$ & -0.339 & 0.946 & -0.030 & 0.089 & -0.030 & 0.078 & -0.023 & 0.056 \\
\hline Store in basin $(1=$ yes, $0=$ no $)$ & -0.048 & 1.514 & -0.004 & 0.125 & 0.004 & 0.138 & -0.004 & 0.109 \\
\hline Store in jar $(1=$ yes, $0=$ no $)$ & 0.110 & 1.616 & 0.034 & 0.116 & 0.010 & 0.155 & 0.009 & 0.132 \\
\hline Store in plastic buckets $(1=$ yes, $0=$ no $)$ & -0.242 & 0.778 & 0.008 & 0.057 & -0.023 & 0.074 & -0.019 & 0.062 \\
\hline${ }^{\mathrm{d} D o y i}$ vovo $(1=$ yes, $0=$ no $)$ & 2.044 & $1.012^{* *}$ & -0.030 & 0.096 & 0.149 & $0.053^{* * *}$ & 0.308 & 0.229 \\
\hline Doyi wiwi $(1=$ yes, $0=$ no $)$ & 1.711 & $0.719^{* * *}$ & 0.016 & 0.054 & 0.150 & $0.057^{* * *}$ & 0.221 & 0.137 \\
\hline /cut $^{e}$ & 2.883 & 1.543 & & & & & & \\
\hline /cut2 ${ }^{\mathrm{e}}$ & 3.976 & 1.574 & & & & & & \\
\hline /cut $^{\mathrm{e}}$ & 5.092 & 1.607 & & & & & & \\
\hline
\end{tabular}

$N=83$, Residual Deviance: 177.9591, AIC (Akaike Information Criteria): 215.9591. Coef. coefficient, Std. Err. standard error *** Significant at $1 \%, * * 5 \%$, and ${ }^{*} 10 \%$

a"Moderately severe" option used as the base category for comparison purposes

bPrimary education used as reference variable

'Store in canaries used as reference variable

${ }^{\mathrm{d} D o y i}$ wéwé used as reference variable

e/cut1, /cut2, and /cut3 are cut-off points in the ordered probit analysis confirming the variables were ordered 
storage insect damage, but they were not statistically significant.

\section{Management of Kersting's groundnut storage insect pests} To limit damage caused by insects on stored Kersting's groundnut grains, most farmers (83.1\%) implemented control methods. Under traditional storage conditions, farmers enumerated seven approaches to control storage insect pests. Among them, the use of chemicals (33.3\% of responses) and the use of insect repellent plants (30.4\% of responses) were the most important. Lamp kerosene (11.6\% of responses), ash (10.2\% of responses), and sand ( $8.7 \%$ of responses) were also used by some farmers. Other strategies such as sun exposure of $M$. geocarpum grains (4.4\% of responses) and the use of ox droppings (1.4\% of responses) were not widely used. Among the chemical pesticides, farmers listed three insecticides and an herbicide (Table 4). These included the herbicide Glyphader 480 and insecticides to protect cotton (KD plus 415), horticultural crops (LAMBDA Super $2.5 \mathrm{EC}$ ), and stored commodities (Sofagrain). Sofagrain is bought at the open market while the other chemicals are obtained from the extension offices of CARDER in their locality. The patterns of use varied depending on the type of chemical used (Table 4). Four plant species listed as repellents included Azadirachta indica A. Juss, Capsicum frutescens L., Citrus sinensis L., and Hyptis suaveolens (L.) Poit. The leaves (A. indica and H. suaveolens) and fruits (C. frutescens and $C$. sinensis) of these plants are the main organs used by farmers.

\section{Discussion}

Our results show that insect attack remains the most important constraint related to the storage of Kersting's groundnut seeds in central and southern Benin, which corroborates previous observations by Assogba et al. (2015). Generally, insect attack remains the main constraint of many stored seed legumes in the tropics (Gbaguidi et al., 2015; Worou et al., 2016), with losses up to 70\% (Guèye, Seck, Wathelet, \& Lognay, 2011; Ngamo \& Hance, 2007). Among the control approaches proposed by farmers, the promotion of Kersting's groundnut varieties resistant to insect pests was the most important.
Indeed, genetic control using tolerant or resistant landraces can be the most practical, economically less expensive, and environmentally friendly way of minimizing the effects of biotic stresses such as insects (Frison, Cherfas, \& Hodgkin, 2011; Mercer \& Perales, 2010). As was the case with voandzou and cowpea farmers in Benin (Gbaguidi et al., 2015), there was a call for breeders to develop new varieties that are insect tolerant and which respond to socioeconomic desire of producers and consumers. However, Kersting's groundnut being a neglected crop, a renewed effort must be sought to assure the needed attention to these farmer requirements for more resistant landraces.

This study revealed that $C$. maculatus is the main pest of stored Kersting's groundnut seeds, confirming the results of Badii et al. (2011) in Ghana. This pest is polyphagous, which explains its presence in most agricultural settings, and hence, the ability to cause substantial damage the stocks of $M$. geocarpum. C. maculatus is also a major cowpea (Vigna unguiculata Walp), and Bambara groundnut (Voandzeia subterranea (L.) Thouars) storage insect in West Africa (Ajayi \& Lale, 2001; Appleby \& Credland, 2003). Because C. maculatus prevents farmers from preserving their seeds for a long time without losses, they usually sell off part of Kersting's groundnut produce immediately after harvest, at a much reduced price (Ayenan \& Ezin, 2016). The higher abundance of $C$. maculatus in the stocks could explain the fact that this species was the only one out of the three present in stored Kersting's groundnut seeds to be recognized by farmers. Farmers have indicated that the palatability of Kersting's groundnut grains and the fragility of their seed coat favor the attacks of insect pests in stocks. In fact, some studies shown that high sugar content (Kosini, Saidou, \& Nukenine, 2017; Podoler \& Applebaum, 1971) and low thick seed coat (Desroches, El Shazly, Mandon, Duc, \& Huignard, 1995; Janzen, 1977; Souza et al., 2011) allow rapid bruchid penetration. It is therefore important for breeders to consider farmers perception on the factors favoring the attack of Kersting's groundnut seeds by insects in the establishment of their varietal improvement program for the benefits of farmers and consumers.

Table 4 List of chemical insecticides used by farmers to protect Kersting's groundnut grains against storage insect pests and their utilization methods

\begin{tabular}{|c|c|c|c|c|}
\hline Trade name & Active ingredient & Chemical family & Mode of use & Place of purchase \\
\hline KD plus 415 & $\begin{array}{l}\text { Lambda-cyhalothrine } 15 \mathrm{~g} / \mathrm{l}+ \\
\text { Chlorpyriphos-éthyl } 400 \mathrm{~g} / \mathrm{l}\end{array}$ & Organophosphate & $\begin{array}{l}\text { Put seeds of } M \text {. geocarpum in empty pesticide } \\
\text { bottles containing pesticide residues }\end{array}$ & Market \\
\hline $\begin{array}{l}\text { Lambda Super } \\
2.5 \mathrm{EC}\end{array}$ & Lambda-cyhalothrine $25 \mathrm{~g} / \mathrm{l}$ & Pyrethroid & & CARDER \\
\hline Glyphader 480 & Glyphosate $480 \mathrm{~g} / \mathrm{l}$ & Amino-phosphonate & & CARDER \\
\hline Sofagrain & Aluminum phosphide & Organophosphate & Put a pill in about $50 \mathrm{~kg}$ of stored $M$. geocarpum seeds & CARDER \\
\hline
\end{tabular}


Various storage containers are used by farmers for post-harvest conservation of Kersting's groundnut seeds. These results are consistent with those of Achigan-Dako and Vodouhè (2006) and Assogba et al. (2015). In alignment with previous report of Assogba et al. (2015), farmers indicated that shelf life of Kersting's groundnut seeds varies from 1 to 12 months depending on the product used for preservation. Heavily infested kersting's groundnut grains are consumed by the interviewed farmers. However, there are reports of a strong relation between insect infestation and aflatoxins contamination in some pulses such as horsegram (Reddy, Brijitha, \& Raghavender, 2005), grass pea (Reddy \& Nusrath, 1983), cowpea, and pigeon pea (Matumba et al., 2017) which are poisonous and contribute to the genesis of primary liver cancer in Africa (Koshio et al., 2017; Peers, Gilman, \& Linsell, 1976). It is therefore urgent to assess the presence of mycotoxins in Kersting's groundnut seeds heavily infested with insects and to raise farmers' awareness on the harmful effects of mycotoxins on human health.

The results indicated that farmers who have university education ranked the severity of insect damage as very severe. A similar result was observed with Midega et al. (2016) which shows the positive influence of level of education on farmers' perception of storage pests of maize in western Kenya. Similar to the result of Midega et al. (2016), the types of storage containers determined the perception of severity of pest attack by farmers. Although the proportion of respondents who stored Kersting's groundnut seeds in jute bags was low, they perceived the pest attack as "not severe." This perception is probably due to the fact that jute bags reduce infestation from one bag to the next by restricting entry or exit of bruchid adults (Lynch, Ouedrago, \& Dicko, 1985). However, some studies shown that stored pulses in jute bags such as cowpea (Arogba, Ugwu, \& Abu, 1998), pigeon pea (Vales, Ranga, Sudini, Patil, \& Murdock, 2014), and mung bean (Mutungi, Affognon, Njoroge, Baributsa, \& Murdock, 2014) were heavily infested with insects. It is so important to evaluate the impact of jute bag on Kersting's groundnut infestation by bruchids. Among the predictors of farmers' perceptions on the severity of storage insect pest attacks, farmers which cultivate Doyi vovo and Doyi wiwi landraces perceived the pest attack as severe. This is surprising because Kersting's groundnut with red and black tegument are known to be resistant to C. maculatus attacks (Badii et al., 2011). In addition, famers identified that Doyi wéwé was the most susceptible landrace to storage insect pests, while Doyi vovo and Doyi wiwi were the most resistant landraces. This perceived level of resistance to insect damages on stored Kersting's groundnut landraces needs to be investigated.

For the control of insect pests in stored M. geocarpum, some farmers use chemicals intended for the protection of cotton and vegetable crops and even herbicides. This dangerous use of non-recommended insecticides and herbicides could have serious consequences for human health and the environment. In fact, most illiterate farmers misuse these chemicals, which lead to cases of intoxication (Ayelo et al., 2015; Ngamo \& Hance, 2007). The sensitization of farmers on the environmental and health risks of pesticides by agents of CARDER which sell pesticide to farmers is imperative. Another negative effect of misuse of pesticides by farmers is the development of insect resistance (Bell \& Wilson, 1995) and the resurgence of highly devastating pests (Bottrell \& Schoenly, 2012). There is therefore a need to develop an alternative control method against insect pests of stored Kersting's groundnut seeds.

For the protection of stored Kersting's groundnut seeds, repellent plants are used by some farmers in the study area. The repellency and insecticidal effects of $A$. indica (Azeez \& Pitan, 2015; Lale \& Abdulrahman, 1999; Tofel, Kosma, Stähler, Adler, \& Nukenine, 2017), H. suaveolens (Azeez \& Pitan, 2015; Sainey, 2016), C. frutescens (Echezona, 2006; Onu \& Aliyu, 1995), and C. sinensis (Dutra, de Oliveira, Navarro, Barbosa, \& Santos, 2016; Oboh et al., 2017) has already been scientifically proven by several studies for the control of $C$. maculatus. Therefore, the use of these plants for the protection of stored products by farmers is to be encouraged. Farmers indicated that they also used some inert products such as kerosene, ash, and sand for the management of insect pests in stored Kersting's groundnut grains, which substantiates previous finding of Assogba et al. (2015). However, all methods used by farmers for pest control are often time-limited and only apply to reduced quantities of seeds. For this, resistant or tolerant varieties of M. geocarpum to attack C. maculatus should be developed for sustainable control of the pest.

\section{Conclusion}

Farmers considered insect pests to be the most important constraint to Kersting's groundnut seeds storage in Benin and proposed the promotion of resistant varieties to overcome this constraint. C. maculatus which is locally designated by six vernacular names was regarded as the main pest of stored Kersting's groundnut seeds. Several factors favoring the attack of Kersting's groundnut seeds by insects have been identified by farmers and need to be considered by the breeders in the establishment of their varietal improvement programs. Various storage containers of Kersting's groundnut seeds have been listed, and their effect on severity of bruchids 
damage must be evaluated. Farmers' perceptions of severity of insect pest damages were significantly influenced by level of education, storage containers, and the type of Kersting's groundnut landraces cultivated. It is hence important to educate farmers about Kersting's groundnut storage insect pests and their damage. Farmers make efforts to control storage insect pest with traditional and chemical methods. Among the three Kersting's groundnut landraces cultivated in Benin, Doyi wéwé was considered by farmers as the most susceptible landrace to storage insect pests, while Doyi vovo and Doyi wiwi as the most resistant landraces. There is therefore a need to confirm these famers' perceptions by the assessment of susceptibility of these landraces to $C$. maculatus.

\section{Abbreviations}

CARDER: Centre Agricole Régional pour le Développement Rural

\section{Acknowledgements}

The authors are thankful to the farmers who participated in the survey. We are also very grateful to anonymous reviewers for helping in the improvement of this manuscript.

\section{Funding}

Not applicable.

\section{Availability of data and materials}

Raw and treated data generated during study are available from the corresponding author on reasonable request.

\section{Authors' contributions}

LYL participated in the study design, analysed and interpreted the data, and drafted the manuscript. AJ, AP and OA carried out interview work. LYL, TJ, DA, and TM corrected the manuscript. All authors approved the final manuscript.

\section{Ethics approval and consent to participate}

As at the time this research was conducted, to the best of our knowledge, there was no committee both at national and institutional level on research ethics involving insect pests. However, all data were collected under previous consent of each participant.

\section{Consent for publication}

Not applicable.

\section{Competing interests}

The authors declare that they have no competing interests.

\section{Publisher's Note}

Springer Nature remains neutral with regard to jurisdictional claims in published maps and institutional affiliations.

\section{Author details}

'Laboratory of Applied Entomology, Faculty of Sciences and Technology of Dassa (FAST-Dassa), National University of Sciences Technologies Engineering and Mathematics of Abomey (UNSTIM), BP 14, Dassa, Benin. ${ }^{2}$ Laboratory of Biotechnology, Genetic Resources and Plant and Animal Breeding (BIORAVE), FAST-Dassa, UNSTIM, BP 14, Dassa, Benin. International Institute of Tropical Agriculture (IITA), 08, BP 0932, Cotonou, Benin.
Received: 16 February 2019 Accepted: 29 May 2019

Published online: 17 June 2019

\section{References}

Achigan-Dako, E. G., \& Vodouhè, S. R. (2006). Macrotyloma geocarpum (Harms) Maréchal and Baudet. In M. Brink, \& G. Belay (Eds.), Plant resources of tropical Africa 1. Cereals and pulses, (pp. 111-114). Wageningen: Backhuys Publishers CTA, PROTA.

Adam, S., \& Boko, M. (1993). Le Bénin. Les éditions du Flamboyant/EDICEF, Cotonou, République du Bénin, (p. 96).

Ajayi, F. A., \& Lale, N. E. (2001). Susceptibility of unprotected seeds and seeds of local Bambara groundnut cultivars protected with insecticidal essential oils to infestation by Callosobruchus maculatus (F.) (Coleoptera: Bruchidae). Journal of Stored Products Research, 37, 47-62.

Ajayi, O. B., \& Oyetayo, F. L. (2009). Potentials of Kerstingiella geocarpa as a health food. Journal of Medicinal Food, 12, 184-187.

Appleby, J. H., \& Credland, P. F. (2003). Variation in responses to susceptible and resistant cowpeas among West African populations of Callosobruchus maculatus (Coleoptera: Bruchidae). Journal of Economic Entomology, 96, 489502.

Arogba, S. S., Ugwu, F. M., \& Abu, J. D. (1998). The effects of sun-drying surfaces and packaging materials on the storability of cowpea (Vigna unguiculata) seed. Plant Foods for Human Nutrition, 53, 113-120.

Assogba, P., Ewedje, E. E. B. K., Dansi, A., Loko, Y. L., Adjatin, A., Dansi, M., \& Sanni, A. (2015). Indigenous knowledge and agro-morphological evaluation of the minor crop Kersting's groundnut (Macrotyloma geocarpum (Harms) Maréchal et Baudet) cultivars of Benin. Genetic Resources and Crop Evolution, 63, 513529.

Ayelo, A. P., Gounongbe, F., Aguemon, B., Akotan, A., Fourn, L., \& Fayomi, B. (2015). Aspects épidémiologiques, cliniques et écosystémiques des intoxications aux pesticides chez les enfants dans le Borgou (Bénin). Rev Int Sci Med Abj, 17, 125-129.

Ayenan, M. A. T., \& Ezin, V. A. (2016). Potential of Kersting's groundnut [Macrotyloma geocarpum (Harms) Maréchal and Baudet] and prospects for its promotion. Agriculture \& Food Security, 5, 10. https://doi.org/10.1186/s40066016-0058-4.

Azeez, O. M., \& Pitan, O. O. R. (2015). Influence of cowpea variety on the potency and deterrent indices of six plant powders against the seed bruchid, Callosobruchus maculatus (Fabricius) (Coleoptera: Bruchidae). Archives of Phytopathology and Plant Protection, 48, 441-451.

Badii, K. B., Asante, S. K., \& Bayorbor, T. B. (2011). Susceptibility of some kersting's groundnut landrace varieties to infestation by Callosobruchus maculatus (Fab. ) [Coleoptera: Bruchidae]. Journal of Science and Technology, 31, 11-20.

Bell, C. H., \& Wilson, S. M. (1995). Phosphine tolerance and resistance in Trogoderma granarium Everts (Coleoptera: Dermestidae). Journal of Stored Products Research, 31, 199-205.

Bottrell, D. G., \& Schoenly, K. G. (2012). Resurrecting the ghost of green revolutions past: The brown planthopper as a recurring threat to highyielding rice production in tropical Asia. Journal of Asia-Pacific Entomology, 15, 122-140.

Chickwendu, N. J. (2007). Chemical composition of four varieties of groundbean (Kerstingiella geocarpa). Journal of Agriculture, Food, Environment and Extension, 6, 73-84.

Dansi, A., Vodouhè, R., Azokpota, P., Yedomonhan, H., Assogba, P., Adjatin, A. Akpagana, K. (2012). Diversity of the neglected and underutilized crop species of importance in Benin. The Scientific World Journal, 2012, 93294719 pages.

Delobel, A., \& Tran, M. (1993). Les Coléoptères des denrées alimentaires entreposées dans les régions chaudes, (p. 424). Paris: ORSTOM.

Desroches, P., El Shazly, E., Mandon, N., Duc, G., \& Huignard, J. (1995). Development of Callosobruchus chinensis (L.) and Callosobruchus maculatus (F.) (Coleoptera: Bruchidae) in seeds of Vicia faba L. differing in their tannin vicine and convicine. Journal of Stored Products Research, 31, 83-89.

Dutra, K. D. A., de Oliveira, J. V., Navarro, D. M. D. A. F., Barbosa, D. R. E. S., \& Santos, J. P. O. (2016). Control of Callosobruchus maculatus (Fabr.) (Coleoptera: Chrysomelidae: Bruchinae) in Vigna unguiculata (L.) WALP. with essential oils from four Citrus spp. Journal of Stored Products Research, 68, 25-32.

Echezona, B. C. (2006). Selection of pepper cultivars (Capsicum spp.) for the control of bruchids Callosobruchus maculatus (F.) on stored cowpea (Vigna unguiculata (L.) Walp.) seeds. African Journal of Biotechnology, 5, 624-628. 
Eze, S. C., Asiegbu, J. E., Mbah, B. N., Orkwor, G. C., \& Asiedu, R. (2006). Effects of four agrobotanical extracts and three types of bags on the control of insect pests and moulds of stored yam chips. Journal of Agriculture, Food, Environment and Extension, 5, 8-12.

Frison, E. A., Cherfas, J., \& Hodgkin, T. (2011). Agricultural biodiversity is essential for a sustainable improvement in food and nutrition security. Sustainability, 3 , 238-253.

Gbaguidi, A. A., Faouziath, S., Orobiyi, A., Dansi, M., Akouegninou, B. A., \& Dansi, A. (2015). Connaissances endogènes et perceptions paysannes de l'impact des changements climatiques sur la production et la diversité du niébé (Vigna unguiculata (L.) Walp.) et du voandzou (Vigna subterranea (L) Verdc.) au Bénin. IJBCS, 9, 2520-2541

Greene, W. H. (2003). Econometric analysis, (5th ed., p. 1026). New York: Prentice Hall.

Guèye, M. T., Seck, D., Wathelet, J. P., \& Lognay, G. (2011). Lutte contre les ravageurs des stocks de céréales et de légumineuses au Sénégal et en Afrique occidentale : synthèse bibliographique. Biotechnologie, Agronomie, Société et Environnement, 15, 183-194.

Haines, C. P. (1989). Observations on Callosobruchus Analis (F.) in Indonesia, including a key to storage Callosobruchus spp (Col., Bruchidae). Journal of Stored Products Research, 25, 9-16.

Halstead, D. G. H. (1986). Keys for the identification of beetles associated with stored products I: Introduction and key to families. Journal of Stored Products Research, 22, 163-203.

Hepper, F. N. (1963). The bambara groundnut (Voandzeia subterranea) and Kersting's groundnut (Kerstingiella geocarpa) wild in West Africa. Kew Bulletin, $16,395-440$

Janzen, D. H. (1977). How southern cowpea weevil larvae (Callosobruchus maculatus) die on non-host seeds. Ecology, 58, 921-927.

Johnston, L. G., \& Sabin, K. (2010). Échantillonnage déterminé selon les répondants pour les populations difficiles à joindre. MIO, 5, 38-48.

Khan, Z. R., Midega, C. A. O., Nyang'au, I. M., Murage, A., Pittchar, J., Agutu, L. O., Pickett, J. A. (2014). Farmers' knowledge and perceptions of the stunting disease of Napier grass in Western Kenya. Plant Pathology, 63, 1426-1435.

Koshio, J., Gao, Y.-T., Dean, M., Egner, P., Nepal, C., Jones, K., Groopman, J. (2017) Association of aflatoxin and gallbladder cancer. Gastroenterology, 153, 488494.

Kosini, D., Saidou, C., \& Nukenine, E. N. (2017). Physico-chemical properties and resistance of ten Bambara groundnut (Vigna subterranea) varieties to attack by Callosobruchus maculatus (Fabricius) (Coleoptera: Chrysomelidae) in the Sudano-sahelian and Sudano-guinean Zones of Cameroon. JEAl, 15, 1-14.

Kouelo, A. F., Antoine, B., Houngnandan, P., Merinosy, F. F. M., Gnimassoun, C. J.-B. , \& Sochime, J. D. (2012). Impact du travail du sol et de la fertilisation minérale sur la productivité de Macrotyloma geocarpum (Harms) Maréchal and Baudet au centre du Bénin. Journal of Applied Biosciences, 51, 3625-3632.

Lale, N. E. S., \& Abdulrahman, H. T. (1999). Evaluation of neem (Azadirachta indica A. Juss) seed oil obtained by different methods and neem powder for the management of Callosobruchus maculatus (F.) (Coleoptera: Bruchidae) in stored cowpea. Journal of Stored Products Research, 35, 135-143.

Loko, Y. L., Dansi, A., Tamo, M., Bokonon-Ganta, A. H., Assogba, P., Dansi, M., Sanni, A. (2013). Storage insects on yam chips and their traditional management in Northern Benin. The Scientific World Journal, 2013, 48453611 pages.

Lynch, R. E., Ouedrago, A. P., \& Dicko, I. (1985). Insect damage to groundnut in semi-arid tropical Africa. In Proceedings of an International Symposium, 21-26 August 1985, Niamey, (pp. 175-183). Patancheru: International Crops Research Institute for the Semi-Arid Tropics (ICRISAT).

Matumba, L., Singano, L., Pungulani, L., Mvula, N., Matumba, A., Singano, C., \& Matita, G. (2017). Aflatoxins, discolouration and insect damage in dried cowpea and pigeon pea in Malawi and the effectiveness of flotation/washing operation in eliminating the aflatoxins. Mycotoxin Research, 33, 129-137.

Mercer, K. L., \& Perales, H. R. (2010). Evolutionary response of landraces to climate change in centers of crop diversity. Evolutionary Applications, 3, 480-493.

Midega, A. O., Nyang'au, I. M., Pittchar, J., Birkett, M. A., Pickett, J. A., Borges, M., \& Khan, Z. R. (2012). Farmers' perceptions of cotton pests and their management in western Kenya. Crop Protection, 42, 193-201.

Midega, C. A. O., Murage, A. W., Pittchar, J. O., \& Khan, Z. R. (2016). Managing storage pests of maize: Farmers' knowledge, perceptions and practices in western Kenya. Crop Protection, 90, 142-149.

Munyuli, T., Cihire, K., Rubabura, D., Mitima, K., Kalimba, Y., Tchombe, N., Mukendi, R. T. (2017). Farmers' perceptions, believes, knowledge and management practices of potato pests in South-Kivu Province, eastern of Democratic Republic of Congo. Open Agriculture, 2, 362-385.
Mutungi, C. M., Affognon, H., Njoroge, A. W., Baributsa, D., \& Murdock, L. L. (2014). Storage of mung bean (Vigna radiata [L.] Wilczek) and pigeonpea grains (Cajanus cajan [L.] Millsp) in hermetic triple-layer bags stops losses caused by Callosobruchus maculatus (F.) (Coleoptera: Bruchidae). Journal of Stored Products Research, 58, 39-47.

Ngamo, L. S. T., \& Hance, T. H. (2007). Diversité de ravageurs et denrées; méthodes alternatives de lutte en milieu tropical. Tropicultura, 25, 215-220.

Norton, G. W., Rajotte, E. G., \& Gapud, V. (1999). Participatory research in integrated pest management: Lessons from the IPM CRSP. Agriculture and Human Values, 16, 431-439.

Oboh, G., Ademosun, A. O., Olumuyiwa, T. A., Olasehinde, T. A., Ademiluyi, A. O., \& Adeyemo, A. C. (2017). Insecticidal activity of essential oil from orange peels (Citrus sinensis) against Tribolium confusum, Callosobruchus maculatus and Sitophilus oryzae and its inhibitory effects on acetylcholinesterase and $\mathrm{Na}+$ / K+-ATPase activities. Phytoparasitica, 45, 501-508.

Okonya, J. S., Mwanga, R. O. M., Syndikus, K., \& Kroschel, J. (2014). Insect pests of sweetpotato in Uganda: Farmers' perceptions of their importance and control practices. Springerplus, 3, 303 http://www.springerplus.com/content/3/1/303.

Onu, I., \& Aliyu, M. (1995). Evaluation of powdered fruits of four peppers (Capsicum spp.) for the control of Callosobruchus maculatus (F) on stored cowpea seed. International Journal of Pest Management, 41, 143-145.

Orobiyi, A., Dansi, A., Assogba, P., Loko, L. Y., Dansi, M., Vodouhè, R., Sanni, A. (2013). Chili (Capsicum annuum L.) in southern Benin: Production constraints, varietal diversity, preference criteria and participatory evaluation. IRJAS, 3(4), 107-120.

Oyetayo, F. L., \& Ajayi, B. O. (2005). Chemical profile and zinc bioavailability on "Hausa groundnut" (Kerstingiella geocarpa). Biosciences, Biotechnology Research Asia, 3, 47-50.

Pasquet, R. S., Mergeai, G., \& Baudoin, J.-P. (2002). Genetic diversity of the African geocarpic legume Kersting's groundnut, Macrotyloma geocarpum (Tribe Phaseoleae: Fabaceae). Biochemical Systematics and Ecology, 30, 943-952.

Peers, G., Gilman, G. A., \& Linsell, C. A. (1976). Dietary aflatoxins and human liver cancer. A study in Swaziland. International Journal of Cancer, 17, 167-176.

Podoler, H., \& Applebaum, S. W. (1971). Host specificity in the Bruchidae-VII. The effect of carbohydrate composition on varietal resistance of garden peas to Callosobruchus chinensis L. Journal of Stored Products Research, 7, 97-102.

Reddy, B. N., Brijitha, N., \& Raghavender, C. R. (2005). Aflatoxin contamination in insect damaged seeds of horsegram under storage. Mycotoxin Research, 21, 187-191.

Reddy, B. N., \& Nusrath, M. (1983). Aflatoxin contamination in normal and insect damaged Kesari (Lathyrus sativus L.) in Andhra Pradesh. Current Science, 52, 370-371.

Sainey, K. (2016). Hyptis suaveolens seed powder as a repellent against Callosobruchus maculatus (Coleoptera: Bruchidae) on cowpea. Indian Journal of Entomology, 78, 293-296.

Souza, A. J., Santos, P. O., Pinto, M. S. T., Wermelinger, T. T., Ribeiro, E. S., Souza, S. C., Oliveira, A. E. A. (2011). Natural seed coats provide protection against penetration by Callosobruchus maculatus (Coleoptera: Bruchidae) larvae. Crop Protection, 30, 651-657.

Tofel, K. H., Kosma, P., Stähler, M., Adler, C., \& Nukenine, E. N. (2017). Insecticidal products from Azadirachta indica and Plectranthus glandulosus growing in Cameroon for the protection of stored cowpea and maize against their major insect pests. Industrial Crops and Products, 110, 58-64.

Vales, M. I., Ranga, R. G. V., Sudini, H., Patil, S. B., \& Murdock, L. L. (2014). Effective and economic storage of pigeonpea seed in triple layer plastic bags. Journal of Stored Products Research, 5, 29-38.

Van Huis, A., \& Meerman, F. (1997). Can we make IPM work for resource-poor farmers in sub- Saharan Africa. International Journal of Pest Management, 43, 313-320.

Worou, D. K., Zandjanakou-Tachin, M., Boulga, J., \& Bokonon-Ganta, A. H. (2016). Diversité des insectes et champignons du maïs, du voandzou, du niébé et de la lentille de terre en stocks dans les marchés du Sud-Bénin. Bulletin de la Recherche Agronomique du Bénin (BRAB), 132-143 http://www.slire.net/ download/2353/14_me_article_brab_brab_n_sp_cial_projet_niche-ben-174_-ao_t_2016.pdf.

Yabi, I., \& Afouda, F. (2012). Extreme rainfall years in Benin (West Africa). Quaternary International, 262, 39-43. 